\title{
PENINGKATAN HASIL BELAJAR MAHASISWA PADA MATA KULIAH IPS MATERI PERKEMBANGAN TEKNOLOGI TRANSPORTASI MELALUI STRATEGI INDEX CARD MATCHSEMESTER III PGMI FITK UIN- SU TAHUN AKADEMIK 2017/2018
}

\section{Eka Yusnaldi}

\begin{abstract}
Abstrak: Penelitian ini bertujuan untuk mengungkapkan Peningkatan Hasil Belajar Mahasiswa pada mata kuliah IPS Materi Perkembangan Teknologi Transportasi Melalui Strategi Index Card Matchsemester III PGMI. Penelitian ini dilaksanakan di Semester III PGMI yang Mahasiswanya berjumlah 33 orang.

Temuan penelitian ini sebagai berikut: (1) Hasil belajar Mahasiswa dalam pembelajaran IPS Semester III melalui strategi Index Card Match tergolong tinggi, (2) Ada peningkatan hasil belajar IPS setelah menggunakan strategi Index Card Matchyang ditunjukkan dengan perbandingan rata-rata hasil belajar Mahasiswa dengan nilai ketuntasan klasikalnya yang dicapai antara pre test $(39,40 \%)$, siklus I $(57,58 \%)$ dan siklus II $(87,88)$, (3) Respon Mahasiswa dengan menggunakan strategi Index Card Match dalam pembelajaran IPS adalah positif.
\end{abstract}

Karena itu, strategi Index Card Matchpada materi perkembangan teknologi transportasi dapat meningkatkan hasil belajar Mahasiswa di Semester III PGMI.

\section{Kata Kunci : Hasil Belajar Mahasiswa dan Strategi Index Card Match}

\section{A. PENDAhULUAN}

Pengertian pendidikan sebagaimana tercantum dalam Undang-Undang No 20 Tahun 2003 tentang Sistem Pendidikan Nasional adalah suatu usaha sadar dan terencana untuk mewujudkan suasana belajar dan proses pembelajaran agar peserta didik secara aktif mengembangkan potensi dirinya untuk memiliki kekuatan spiritual keagamaan, pengendalian diri, kepribadian, kecerdasan, akhlak mulia serta keterampilan yang diperlukan dirinya, masyarakat, bangsa dan Negara.

Belajar adalah suatu proses pembelajaran yang merubah diri seseorang, yang tadinya tidak tahu menjadi tahu yang tidak mengerti menjadi mengerti. Belajar juga dapat dikatakan sebagai proses interaksi antara manusia dengan lingkungannya, sehingga menghasilkan perubahan tingkah laku yang bersifat positif, baik perubahan dalam pengetahuan maupun sikap, maupun psikomotorik.

Dalam meningkatkan proses pembelajaran dikampus, dosen diharapkan dapat melaksanakan kegiatan pembelajaran dengan baik. Untuk itu diperlukan kecermatan dosen memilih dan menerapkan serta menyusun strategi pembelajaran. Salah satu diantaranya ialah 
dengan menggunakan suatu strategi. Dengan adanya penggunaan strategi dalam proses pembelajaran, diharapkan membuat para Mahasiswa aktif dalam proses pembelajaran.

Berdasarkan hasil pengamatan peneliti di PGMI FITK UIN- SU, diketahui bahwa pembelajaran yang dilakukan oleh dosen di kelas, khususnya pada Mata Kuliah IPS masih kurang efektif. Hal ini terlihat dari proses pembelajaran yang dilakukan dosen, dimana pada saat menyampaikan materi pelajaran dosen cenderung menggunakan teknik seperti ceramah, mencatat, serta penugasan Mahasiswa dituntut mandiri walaupun Mahasiswa tidak mengerti. Sehingga terlihat Mahasiswa hanya berkhayal dan menebak - nebak tentang materi pelajaran yang disampaikan dosen. Akibatnya Mahasiswa cenderung pasif dan kurang antusias serta kurang berminat terhadap materi yang dipelajarinya. Selain itu juga terlihat di wajah Mahasiswa adanya kebosanan atau kejenuhan terhadap pelajaran tersebut.

Hasil belajar adalah perubahan tingkah laku yang mencakup bidang kognitif, afektif, dan psikomotorik. Melalui proses belajar seseorang akan mengalami perubahan dalam tingkah lakunya yakni sebagai hasil belajar yang dilakukannya. Proses belajar mengajar dan hasil belajar merupakan dua hal yang tidak dapat dipisahkan. Untuk itu, maka segala sesuatu yang mempengaruhi proses belajar harus dioptimalkan agar mencapai proses belajar yang lebih baik.

Maka untuk dapat meningkatkan hasil belajar Mahasiswa dalam belajar IPS, dibutuhkan penggunaan strategi pembelajaran yang tepat. Sehingga perlu diupayakan suatu strategi pembelajaran yang memfokuskan Mahasiswa untuk berpartisipasi aktif dalam proses pembelajaran, mampu mengembangkan kemampuan belajar, menemukan sendiri dan membangun sendiri pengetahuannya.

Melihat hal ini, maka peneliti berusaha menemukan strategi pembelajaran yang tepat untuk diterapkan, karena strategi pembelajaran yang telah dilaksanakan selama ini kurang maksimal. Agar proses pembelajaran lebih bermakna, peneliti mencoba menggunakan strategi pembelajaran Index Card Match bagi Mahasiswa, dengan menggunakan strategi pembelajaran ini diharapkan Mahasiswa dapat lebih aktif dalam belajar dan dapat membentuk pengetahuannya sendiri dan dapat belajar mandiri. Peneliti menganggap strategi pembelajaran Index Card Match adalah solusi atas masalah - masalah yang dihadapi pada pelajaran IPS. Strategi Index Card Match merupakan suatu strategi pembelajaran yang mengajak Mahasiswa untuk belajar aktif dan bertujuan agar Mahasiswa mempunyai jiwa kemandirian dalam belajar serta menumbuhkan daya kreatifitas. 


\section{ISSN2086-4205}

\section{B. LANDASAN TEORI}

\section{STRATEGI INDEX CARD MATCH}

Strategi Index Card Match adalah strategi yang dikembangkan untuk menjadikan Mahasiswa aktif mempertanyakan gagasan orang lain dan gagasan diri sendiri dan seorang Mahasiswa memiliki kreatifitas maupun menguasai ketrampilan yang diperlihatkan untuk mencapai tujuan pembelajaran. Pembelajaran yang bernuansa inovatif tentu sangat dibutuhkan dalam kondisi kelas yang sangat menyenangkan atau ada kebebasan, sehingga Mahasiswa dapat tumbuh dan berkembang sebagaimana mestinya.

StrategiIndex Card Match merupakan strategi yang ciptakan kondisi pembelajaran yang bersifat kerjasama, saling menolong dan tanggungjawab dalam menyelesaikan tugas yang diberikan lewat permainan kartu. Hal ini bukanlah hal baru dalam dunia Islam, karena Islam sendiripun menganjurkan untuk tolong menolong dalam kebaikan.

Menurut Mel Silberman dalam bukunya Active Learning, strategi Index Card Match merupakan kegiatan kolaboratif yang biasa digunakan untuk mengerjakan konsep,penggolongan sifat, fakta tentang suatu objek, atau mengulangi informasi. Cara ini memungkinkan Mahasiswa untuk berpasangan dan memberi pertanyaan kuis kepada temannya.

Strategi pembelajaran Index Card Match adalah strategi pembelajaran aktif dan menyenangkan yang cara kerjanya adalah mencari pasangan kartu dimana kartu tersebut berisi kartu soal dan kartu jawaban yang menuntut Mahasiswa untuk bekerja sama dalam mencari pasangan kartu. Strategi ini tepat digunakan untuk melibatkan Mahasiswa dalam kegiatan belajar karena melalui strategi Index Card MatchMahasiswa dapat berinteraksi dengan dosen ataupun Mahasiswa lainnya. Selain itu Mahasiswa juga dapat menggali kembali pengetahuan yang diperolehnya selama mengikuti pembelajaran.

\section{Langkah-langkah Penggunaan Strategi Index Card Match}

Menurut Istarani langkah-langkah pembelajaran strategi Index Card Match adalah sebagai berikut :

a. Mempersiapkan segala jenis dan bentuk peralatan untuk memotong kertas dalam pembuatan kartu. 
a. Buatlah potongan-potongan kertas sebanyak jumlah Mahasiswa yang ada di dalam kelas.

b. Bagilah kertas-kertas tersebut menjadi dua bagian yang sama.

c. Pada separuh bagian, tulis pertanyaan tentang materi yang akan dibelajarkan. Setiap kertas berisi satu pertanyaan.

d. Pada separuh kertas yang lain, tulis jawaban dari pertanyaan-pertanyaan yang telah dibuat.

e. Kocoklah semua kertas sehingga akan tercampur antara soal dan jawaban.

f. Setiap Mahasiswa diberi satu kertas. Jelaskan bahwa ini adalah aktivitas yang dilakukan berpasangan. Separuh Mahasiswa akan mendapatkan soal dan separuh yang lain mendapatkan jawaban.

g. Mintalah kepada Mahasiswa untuk menemukan pasangan mereka. Jika ada yang sudah menemukan pasangan, mintalah kepada mereka untuk duduk berdekatan. Jelaskan juga agar mereka tidak memberitahu materi yang mereka dapatkan kepada teman yang lain.

h. Setelah semua Mahasiswa menemukan pasangan dan duduk berdekatan, mintalah kepada setiap pasangan secara bergantian untuk membacakan soal yang diperoleh dengan keras kepada teman-teman yang lain. Selanjutnya soal tersebut dijawab oleh pasangannya.

i. Akhiri proses ini dengan membuat klasifikasi dan kesimpulan.

\section{Keunggulan dan Kelemahan Strategi Index Card Match}

Strategi Index Card Match memiliki kelebihan dan kekurangan. Menurut Istarani (2012) menyatakan bahwa terdapat kelebihan dan kelemahan strategi Index Card Match sebagai berikut :

1) Kelebihan dari strategi Index Card Match yaitu :

a. Pembelajaran akan menarik sebab menggunakan media kartu yang dibuat dari potongan kertas

b. Meningkatkan kerjasama diantara Mahasiswa melalui proses pembelajaran

c. Dengan pertanyaan yang diajukan akan mendorong Mahasiswa untuk mencari jawaban

d. Menumbuhkan kreatifitas belajar Mahasiswa dalam proses belajar mengajar

2) Kelemahan dari strategi Index Card Match yaitu : 


\section{ISSN2086-4205}

a. Potongan-potongan kertas kurang dipersiapkan secara baik

b. Tulisan dalam kartu adakalanya tidak sesuai dengan bentuk kartu yang ada

c. Kurang memadukan materi dengan kebutuhan Mahasiswa

Sedangkan menurut Handayani dalam Margana (2010) menyatakan bahwa terdapat kelebihan dan kelemahan strategi Index Card Match sebagai berikut :

1) Adapun kelebihan dari strategi Index Card Match yaitu :

a. Menumbuhkan kegembiraan dalam kegiatan belajar mengajar

b. Materi pelajaran yang disampaikan lebih menarik perhatian Mahasiswa

c. Mampu menciptakan suasana belajar yang aktif dan menyenangkan

d. Mampu meningkatkan prestasi belajar Mahasiswa mencapai taraf ketuntasan belajar

e. Penilaian dilakukan bersama pengamat dan pemain

2) Adapun kekurangan dari strategi Index Card Match yaitu :

a. Membutuhkan waktu yang lama bagi Mahasiswa untuk menyelesaikan tugas dan prestasi

b. Dosen harus meluangkan waktu yang lebih lama untuk membuat persiapan

c. Dosen harus memiliki jiwa demokratis ketrampilan yang memadai dalam hal pengelolaan kelas

d. Menuntut sifat tertentu dari Mahasiswa atau kecenderungan untuk bekerja sama dalam menyelesaikan masalah

e. Suasana kelas menjadi "gaduh" sehingga dapat mengganggu kelas lain

Berdasarkan kelebihan dan kekurangan strategi Index Card Match sebisa mungkin dosen dituntut untuk dapat mengantisipasi kekurangan yang terdapat dalam penerapan strategi Index Card Match terutama penerapannya dalam pembelajaran IPS. Antisipasi tersebut dapat diwujudkan dosen melalui berpikir kritis, inovatif, dan kreatif dalam melaksanakan suatu pembelajaran agar Mahasiswa dapat belajar secara aktif. Strategi Index Card Match dirasa cocok untuk diterapkan dalam pembelajaran IPS karena strategi pembelajaran Index Card Match merupakan salah satu strategi pembelajaran aktif dimana Mahasiswa akan terlibat langsung dalam membangun pengetahuannya, menarik perhatian Mahasiswa karena ada unsur permainan yang dapat membangun kebersamaan dan keakraban antar Mahasiswa.

2. HAKIKAT ILMU PENGETAHUAN SOSIAL (IPS) 
Ilmu Pengetahuan Sosial, seperti halnya IPA, Matematika dan Bahasa Indonesia merupakan bidang studi. Dengan demikian, IPS sebagian bidang studi memiliki garapan yang dipelajarai cukup luas. Bidang garapannya meliputi gejala-gejala dan masalah kehidupan manusia di masyarakat. Tekanan yang dipelajarai IPS berkenaan dengan gejala-gejala dan masalah kehidupan masyarakat bukan pada teori dan keilmuannya saja, melainkan juga pada kenyataan kehidupan masyarakat yang nyata. Dari gejala-gejala dan masalah yang ditelaah, dianalisis faktor-faktor sehingga dapat dirumuskan cara pemecahan masalahnya.

IPS merupakan salah satu Mata Kuliah di PGMI yang terdiri dari dua bahan kajian pokok, yaitu pengetahuan sosial dan sejarah. Pengetahuan sosial mencakup antropologi, geografi, ekonomi, dan tata Negara. Bahan kajian sejarah meliputi perkembangan masyarakat Indonesia sejak masa lalu hingga masa kini.

Ilmu Pengetahuan Sosial (IPS) merupakan integrasi dari barbagai cabang ilmu-ilmu sosial seperti sosiologi, sejarah, geografi, ekonomi, politik, hukum, dan budaya. Ilmu pengetahuan sosial dirumuskan atas dasar realitas dan fenomena sosial yang mewujudkan satu pendekatan interdisipliner dari aspek dan cabang-cabang ilmu-ilmu sosial (sosiologi, sejarah, geografi, ekonomi, politik, hukum dan budaya).

Mata Kuliah IPS disusun secara sistematis, komprehensif, dan terpadu dalam proses pembelajaran menuju kedewasaan dan keberhasilan dalam kehidupan di masyarakat. Dengan pendekatan tersebut diharapkan peserta didik akan memperoleh pemahaman yang lebih luas dan mendalam pada bidang ilmu yang berkaitan.

Tujuan utama IPS adalah untuk mengembangkan potensi peserta didik agar peka terhadap masalah sosial yang terjadi di masyarakat, memiliki sikap mental positif terhadap perbaikan gejala ketimpangan yang terjadi, dan terampil mengatasisetiap masalah yang dihadapi sehari-hari, baik yang menimpa dirinya maupun yang menimpa masyarakat.Demikian pula belajar dengan ilmu pengetahuan sosial (IPS) yang dilakukan oleh Mahasiswa, atau pembelajaran yang dilakukan oleh dosen adalah usaha untuk mengubah Mahasiswa melalui keterampilan, sikap dan nilai-nilai dalam IPS. IPS yang dimaksud adalah ilmu kemasyarakatan (sosiologi, geografi, sejarah) ilmu pengetahuan sosial berbeda dengan ilmu pengetahuan alam yang mempelajari segala sesuatu dari sudut pandang eksakta.

\section{MATERI PERKEMBANGAN TEKNOLOGI TRANSPORTASI}

Sarana pengangkutan disebut juga alat transportasi. Alat-alat tranportasi yang ada sekarang ini mengalami proses perkembangan yang panjang. Dulu orang menggunakan alat 
transportasi yang masih sangat sederhana. Bahkan pada zaman dahulu orang berpergian hanya berjalan kaki. Sekarang orang sudah memakai alat transportasi modern. Alat atau sarana tranportasi yang digunakan dewasa ini terdiri dari transportasi darat, transportasi air, dan transportasi udara. Ketiga kelompok transportasi ini akan dibahas di bawah ini.

a. Transportasi Darat

Sarana angkutan melalui jalan darat disebut transportasi darat. Alat transportasi darat berkembang dari yang sederhana sampaike yang modern. Pada zaman dulu orang berjalan kaki untuk pergike suatu tempat. Seiring perjalanan waktu, manusia akhirnya memanfaatkan beberapa jenis binatang seperti unta, keledai, kuda, gerobak yang ditarik lembu, dan kereta kuda sebagai alat transportasi.

Angkutan darat dibedakanmenjadi dua jenis, yaitu bermesin dan tidak bermesin. Angkutan tidak bermesin bersifat tradisional berlangsung sejak dahulu. Misalnya, sepeda, becak, delman, gerobak, dan sebagainya. Transportasi yang tidak menggunakan mesin umumnya menggunakan hewan.Hewan-hewan itu biasanya hewan besar, seperti kuda, sapi, unta dan sebagainya.Angkutan darat yang menggunakan mesin bersifat modern harganya lebih mahal dan dayaangkut lebih cepat. Contohnya, sepeda motor, mobil, bus, kereta api, dan sebagainya.

Teknologi yang digunakan untuk membuat mobil sudah berkembang. Mobil pertama dibuat di Jermanpada tahun 1880. Orang-orang yang terkenal sebagai pembuat mobiladalah Carl Benz, Henry Ford, dan Suzuki.Pada zaman sekarang sudah ada banyak jenis mobil. Ada mobilsedan, bus tingkat, bus gandeng, truk yang rodanya ada 6 sampaitruk yang rodanya 14 , mobil balap, dan sebagainya.

Angkutan darat yang lain adalah kereta api. Kereta api mampu mengangkut lebih banyak orang dibandingkan dengan bus. Kereta api juga lebih cepat dibandingkanbus. Rangkaian kereta api ditarik oleh sebuah lokomotif.Teknologi yang digunakan kereta api pun berkembang. Zamandulu, lokomotif digerakkan dengan mesin uap. Uap air itu diperolehdengan memanaskan air yang ada di dalam ketel besar. Bahan bakaryang dipergunakan untuk lokomotif bermesin uap adalah batu baraatau kayu bakar. Kereta api zaman sekarang digerakkan dengan tenaga mesin diesel atau tenaga listrik. Di Indonesia perjalanan kereta api diselenggarakan oleh PT KAI (PTKereta Api Indonesia). PT KAI ini sebelumnya bernama PJKA (Perusahaan Jawatan Kereta Api).

b. Transportasi Air 
Transportasi air adalah alat transportasi yang digunakan disungai, danau, dan laut. Jenis angkutan air dapat kita kelompokkan menjadi dua, yaitu alat transportasi air bermesin dan alat transportasiair tidak bermesin. Contoh tidakbermesin, seperti perahu dayung, kapal layar, dansebagainya. Adapun yang bermesin adalah kapal laut.Kapal laut ada yang berukuran besar dan kecil. Kapalyang besar dapat mengangkut bus, truk, dan sebagainya.

Kapal layar pada zaman dahulu mengandalkan hembusan angin dan digerakkan dengan baling-baling di dalam air. Sebelum mesin uap ditemukan, kapal digerakkan dengan layar dan dayung. Jadi, zaman dahulu orang berlayar bergantung pada angin dan pada zaman dahulu kalau orang berlayar bisa lama sekali. Zaman sekarang sudah berbeda, kapal sudah digerakkan dengan mesin diesel, mesin uap dan ada juga kapal yang digerakkan dengan tenaga nuklir. Perakitan kapal di dalam negeri, yaitu PT PAL diSurabaya (Jawa Timur). Adapun PT Pelni merupakanperusahaan pemerintah yang mengelola transportasi laut.

\section{c. Transportasi Udara}

Transportasi udara di Indonesiatelah berkembang, perkembangannya itu ke arah kemajuan. Angkutan udara lebih mahal dibandingkan angkutan lainnya. Waktu tempuh angkutanudara lebih cepat.

Ada macam-macam alat transportasi udara. Selain pesawat udara, ada balon udara dan helikopter. Balon udara pertama kali dibuat pada tahun1783, nama pembuatnya adalah Montgolifer. Balon udara ini dapat terbang karena diberi udara panas dan udara panas ini berasal dari hidrogen yang dibakar. Jika pemanas dinyalakan, balon akan naik dan jika udara di dalam balon menjadi dingin, balon akan turun. Sekarang gas hidrogen tidak dipakai lagi untuk menerbangkan balon karena mudah terbakar. Sebagai gantinya, orang sekarang memakai gas helium yang tidak mudah terbakar.

Alat transportasi udara yang lebih modern adalah pesawat udara. Pesawat untuk mengangkut penumpang dikembangkan sesudah Perang Dunia I. Pesawat yang pertama kali dibuat digerakkan dengan baling-baling dan sekarang pesawat penumpang sudah menggunakan jet.

Angkutan udara di Indonesia ditangani oleh Departemen Perhubungan RI.Penerbangan yang diusahakan pemerintah, yaitu Garuda Indonesia. Adapunpenerbangan swasta adalah Mandala, Batavia, Lion, dan sebagainya. Industri pesawatterbang Indonesia terdapat di Bandung (Jawa Barat).

\section{PEMBAHASAN HASIL PENELITIAN}




\section{ISSN2086-4205}

Berdasarkan paparan hasil penelitian yang telah dilakukan terhadap MahasiswaSemester IIIPGMI FITK UIN- SU pada mata Kuliah IPS, maka dapat diketahui adanya peningkatan hasil belajar Mahasiswa dengan menggunakan strategi Index Card Match. Strategi Index Card Match lebih menarik perhatian Mahasiswa dan mampu menciptakan suasana belajar yang menyenangkan. Melalui strategi Index Card Match materi pembelajaran yang dipelajari lebih mudah diserap sehingga dapat meningkatkan tingkat pemahaman Mahasiswa selama mengikuti kegiatan pembelajaran.

Berdasarkan pre test yang diberikan oleh dosen sebelum dilakukan sebuah tindakan, dapat diketahui bahwa dari 33 Mahasiswa, hanya 13 Mahasiswa $(39,40 \%)$ yang telah mencapai ketuntasan dan 20 Mahasiswa (60,60\%) yang belum mencapai ketuntasan belajar. Hal ini menunjukkan bahwa masih banyak Mahasiswa yang belum menguasai materi perkembangan teknologi transportasi.

Untuk meningkatkan hasil belajar IPS Mahasiswa dilaksanakan siklus I dengan menggunakan strategi Index Card Match. Hal ini telah dibuktikan dengan perolehan pada siklus I, dari 33 Mahasiswa terdapat 19 Mahasiswa (57,58\%) yang telah mencapai ketuntasan dan 14 Mahasiswa (42,42\%) yang tidak mencapai ketuntasan belajar. Jadi, hasil ketuntasan belajar secara klasikal yang diperoleh Mahasiswa sebesar 57,58\%.

Siklus II dilakukan dengan pengembangan dan perbaikan dari siklus I. Perolehan ketuntasan belajar Mahasiswa yang belum tuntas pada siklus I dapat disebabkan karena kurangnya motivasi dan keaktifan Mahasiswa dalam proses belajar megajar. Oleh sebab itu, peneliti perlu melakukan perbaikan-perbaikan tindakan dalam menyelesaikan pembelajaran yang dapat meningkatkan motivasi dan keaktifan Mahasiswa. Kurangnya motivasi dan keaktifan Mahasiswa pada siklus I dapat ditingkatkan pada siklus II dengan lebih mendekatkan diri kepada Mahasiswa.

Hasil belajar siklus II dapat dikatakan tuntas karena dari 33 Mahasiswa terdapat 29 Mahasiswa $(87,88 \%)$ yang telah mencapai ketuntasan belajar dan diperoleh 4 Mahasiswa $(12,12 \%)$ yang tidak mencapai ketuntasan. Dan hal ini sudah mencapai ketuntasan belajar Mahasiswa yang diharapkan peneliti.

Sedangkan observasi kemampuan dosen dalam mengelola pelajaran pada siklus I memperoleh nilai sebesar 3,3. Dengan nilai-nilai yang diperoleh tersebut, menunjukkan bahwa kemampuan dosen berjalan dengan baik. Tetapi, ini belumlah maksimal maka peneliti mengadakan pengamatan lanjutan ke siklus II dengan kemampuan dosen memperoleh nilai 
sebesar 3,6. Sedangkan respon Mahasiswa pada siklus I mengalami peningkatan di siklus II. Berdasarkan hasil-hasil yang telah dicapai, ini membuktikan terjadinya peningkatan pada setiap siklusnya.

\section{KESIMPULAN DAN SARAN}

Kesimpulan

Berdasarkan hasil penelitian yang telah dilaksanakan, maka diperoleh kesimpulan sebagai berikut :

1. Hasil belajar Mahasiswa sebelum menggunakan strategi Index Card Match dapat dikatakan rendah karena dilihat dari pre test atau tes awal Mahasiswa diperoleh 20 Mahasiswa (60,60\%) yang baru mencapai tingkat ketuntasan belajar dengan nilai ratarata yang diperoleh yaitu 58,78 .

2. Terjadi peningkatan hasil belajar Mahasiswa setelah diterapkannya strategi Index Card Match. Hal ini dapat terlihat dari hasil belajar siklus I diperoleh 19 Mahasiswa (57,58\%) yang telah mencapai ketuntasan dengan nilai rata-rata yang diperoleh 69,39. Pada hasil belajar siklus II diperoleh 29 Mahasiswa (87,88\%) yang telah mencapai ketuntasan belajar dengan nilai rata-rata yang diperoleh 80,30 .

3. Respon Mahasiswaterhadap penggunaan strategi Index Card Match dalam proses pembelajaran dinilai sangat baik, hal ini terbukti dari lembar observasi Mahasiswa pada setiap siklus.

Saran

Berdasarkan hasil pembahasan penelitian, maka peneliti menyarankan :

1. Bagi dosen hendaknya menggunakan strategi Index Card Match dalam pembelajaran sehingga penggunaan strategi ini dapat dikembangkan untuk pokok bahasan lainnya guna menarik minat Mahasiswa dalam proses pembelajaran sehingga dapat meningkatkan hasil belajar Mahasiswa.

2. Bagi ketua Prodi diharapkan dapat memberikan dukungan dalam pemilihan strategi pembelajaran untuk perbaikan pembelajaran terkait penerapan strategi Index Card Match.

3. Bagi Mahasiswa, pembelajaran dengan menggunakan strategi Index Card Match diharapkan Mahasiswa dapat terlibat aktif dalam pembelajaran IPS.

\section{DAFTAR PUSTAKA}




\section{ISSN2086-4205}

Aqib, Zainal, dkk. 2009. Penelitian Tindakan Kelas untuk dosen SD, SLB dan TK. Bandung: Yrama Widya.

Dewi, Rosmala. 2010.Profesionalisasi Dosen Melalui Penelitian Tindakan Kelas. Medan:Pasca Sarjana Unimed.

Halimah, Siti. 2010.Telaah Kurikulum . Medan: Perdana Publishing.

Hamalik, Oemar. 2001.Perencanaan Pengajaran Berdasarkan Pendekatan Sistem.Jakarta: Bumi Aksara.

Hanafiah, Nanang dan Cucu Suhana, 2010. Konsep Strategi Pembelajaran. Bandung : PT. Refika Aditama.

Moleong, Lexy J. 2010. Metodologi Penelitian Kualitatif. Bandung: PT Remaja Rosdakarya.

Istarani. 2012.58 Model Pembelajaran Inovatif Referensi Dosen dalam Menentukan Model Pembelajaran. Medan.

Sanjaya, Wina. 2009. Kurikulum dan Pembelajaran. Jakarta : Kencana. . 2010.Strategi Pembelajaran Berorientasi Standar Proses Pendidikan. Jakarta: Kencana.

Sardiman, AM. 2009. Interaksi \& Motivasi Belajar Mengajar. Jakarta: PT. Raja Grafindo Persada.

Shabir, Muslich. 1981. Terjemah Riyadlus Shalihin II. Semarang: CV. Toha Putra.

Shihab, M.Quraisy. 2002. Tafsir Al-Misbah: Pesan, Kesan, dan Keserasian AlQur'an.Jakarta: Lentera Hati.

Siberman, Melvin L. 2006. Active Learning. Bandung : Nusamedia.

Slameto. 2010. Belajar dan Faktor-Faktor yang Mempengaruhinya.Jakarta : Rineka Cipta.

Sudjana, Nana. 2003. Penilaian Hasil Belajar Mengajar. Jakarta: Remaja Rosdakarya.

Suprijono, Agus. 2009. Cooperatif Learning: Teori dan Aplikasi Paikem. Surabaya: Pustaka Pelajar.

Syah, Muhibbin. 2011.Psikologi Belajar. Jakarta : Rajawali Pers.

Trianto. 2010. Model Pembelajaran Terpadu, Konsep, Strategi, dan Implementasinya dalam Kurikulum Tingkat Satuan Pendidikan (KTSP). Jakarta : Bumi Aksara. 